\title{
Cryopreservation of Mycobacterium bovis isolates
}

\section{Criopreservação de isolados de Mycobacterium bovis}

\author{
Cássia Yumi Ikuta ${ }^{1 *}$; Simone Rodrigues Ambrosio ${ }^{1}$; \\ Antonio Francisco de Souza Filho ${ }^{4}$; José Henrique Hildebrand Grisi-Filho²; \\ Marcos Bryan Heinemann²; José Soares Ferreira Neto²; Marcos Amaku ${ }^{3}$
}

\begin{abstract}
Research, development of new biotechnological methods, diagnostic tests, confirmation of results, and reinvestigations are possible because of the availability of well-preserved living organisms maintained without any changes. Cryopreservation is a simpler, more reliable and long-term stable method for culture maintenance. Storage temperature and composition of the suspending vehicle are factors that affect the viability of mycobacterial strains. Three vehicles and three storage temperatures were evaluated to define a suitable cryoprotective medium for the preservation of Mycobacterium bovis strains. Colonies of sixteen M. bovis isolates were used to prepare the suspensions, which were then added to three vehicles: sterile $0.85 \%$ saline solution (SS), Middlebrook 7H9 broth (7H9), and Middlebrook 7H9 broth with sodium pyruvate (7H9p) replacing glycerol. Aliquots of these suspensions were frozen by three different methods, directly in the $-20^{\circ} \mathrm{C}$ freezer, directly in the $-80^{\circ} \mathrm{C}$ freezer, and at $-196^{\circ} \mathrm{C}$ by immersion in liquid nitrogen (LN). The frozen aliquots were thawed at room temperature after 45,90 and 120 days. Mycobacterial viability was assessed by counting the living cells on plates of Stonebrink medium before and after the freezing procedure. Storage at $-20^{\circ} \mathrm{C}$ exhibited a lower recovery of $M$. bovis compared to storage at $-80^{\circ} \mathrm{C}$ (Dunn's test, $\mathrm{p}=0.0018$ ) and LN (Dunn's test, $\mathrm{p}=0.0352$ ). There was no statistically significant difference between storage at $-80^{\circ} \mathrm{C}$ and in $\mathrm{LN}$ (Dunn's test, $\mathrm{p}=0.1403$ ), yet $-80^{\circ} \mathrm{C}$ showed better results than LN. All three suspending vehicles showed no statistically significant difference in terms of viability (Friedman's test, $\mathrm{p}=0.7765$ ). Given the low loss proportion of $5 \%$ during storage at $-20^{\circ} \mathrm{C}$ and the high cost equipment required for storage at $-80^{\circ} \mathrm{C}$ and $\mathrm{LN}$, we recommend storage at $-20^{\circ} \mathrm{C}$ or $-80^{\circ} \mathrm{C}$, when this is available, for preservation of $M$. bovis field strains.
\end{abstract}

Key words: Cryopreservation. Middlebrook $7 \mathrm{H} 9$ broth. Mycobacterium bovis.

\section{Resumo}

Pesquisa, desenvolvimento de novos métodos biotecnológicos, testes diagnósticos, confirmação de resultados e reinvestigações são possíveis por causa da disponibilidade de organismos vivos bem preservados e mantidos inalterados. A criopreservação tem mostrado ser um método de manutenção de cultura mais simples, mais confiável e estável em longo prazo. Temperatura de armazenamento e composição do veículo de suspensão são fatores que afetam a viabilidade de cepas micobacterianas. Três veículos e três temperaturas de armazenamento foram avaliados para definir um meio crioprotetor adequado para preservação de estirpes de Mycobacterium bovis. Colônias de 16 isolados de M. bovis

1 Pesquisadores, Faculdade de Medicina Veterinária e Zootecnia, Universidade de São Paulo, USP, São Paulo, SP, Brasil. E-mail: cassiayi@yahoo.com.br; simone.ambrosio@yahoo.com.br

2 Profs., Faculdade de Medicina Veterinária e Zootecnia, USP, São Paulo, SP, Brasil. E-mail: grisi@vps.fmvz.usp.br; marcosbryan@ usp.br; jsoares@vps.fmvz.usp.br

3 Prof., Faculdade de Medicina, USP, São Paulo, SP, Brasil. E-mail: amaku@vps.fmvz.usp.br

4 Discente, Curso de Doutorado do Epidemiologia Experimental aplicada às Zoonoses. Faculdade de Medicina Veterinária e Zootecnia, USP, São Paulo, SP, Brasil. E-mail: antoniosouzafilho@gmail.com

* Author for correspondence 
foram usadas na preparação de suspensões, as quais foram adicionadas a três veículos: solução salina a 0,85\% estéril, caldo Middlebrook 7H9 (7H9) e caldo Middlebrook 7H9 com piruvato de sódio (7H9p) substituindo o glicerol. Alíquotas dessas suspensões foram congeladas por três métodos diferentes, direto em freezer a $-20^{\circ} \mathrm{C}$, direto em freezer a $-80^{\circ} \mathrm{C}$ e a $-196^{\circ} \mathrm{C}$ por imersão em nitrogênio líquido (LN). As amostras foram descongeladas a temperatura ambiente após 45, 90 e 120 dias. A viabilidade das micobactérias foi avaliada pela contagem de células vivas em placas com meio Stonebrink, antes e depois dos processos de congelamento. Armazenamento a $-20^{\circ} \mathrm{C}$ exibiu menor recuperação de $M$. bovis comparado a $-80^{\circ} \mathrm{C}$ (Teste de Dunn, $\mathrm{p}=0.0018$ ) e $\mathrm{LN}$ (Teste de Dunn, $\mathrm{p}=0.0352$ ). Não houve diferença entre armazenamento a $-80^{\circ} \mathrm{C}$ e LN (Teste de Dunn, $\mathrm{p}=0.1403$ ), mas $-80^{\circ} \mathrm{C}$ apresentou melhores resultados do que LN. Os três veículos de suspensão não apresentaram diferença estatística (Teste de Friedman, $\mathrm{p}=0.7765)$. Dada à baixa proporção de perda $(5 \%)$ durante o armazenamento a $-20^{\circ} \mathrm{C}$ e ao alto custo do equipamento necessário para o armazenamento a $-80^{\circ} \mathrm{C}$, nós recomendamos o armazenamento a $-20^{\circ} \mathrm{C}$ ou $-80^{\circ} \mathrm{C}$, quando disponível, para a preservação das estirpes de campo de M. bovis.

Palavras-chave: Criopreservação. Caldo Middlebrook 7H9. Mycobacterium bovis.

\section{Introduction}

Recent studies carried out in 13 states of Brazil, that hold $75 \%$ of the Brazilian cattle population, showed prevalence of tuberculosis infected herds between 0.36\%, in the Federal District, and 9.0\%, in São Paulo (BAHIENSE et al., 2016; BARBIERI et al., 2016; DIAS et al., 2016; GALVIS et al., 2016; GUEDES et al., 2016; LIMA et al., 2016; NÉSPOLI et al., 2016; QUEIROZ et al., 2016; RIBEIRO et al., 2016; ROCHA et al., 2016; SILVA et al., 2016; VELOSO et al., 2016; VENDRAME et al., 2016).

The success of the Brazilian Program of Control and Eradication of Brucellosis and Tuberculosis (PNCEBT) relies on the surveillance system based on isolation of Mycobacterium bovis from suspected tuberculous lesions obtained from abattoirs (LAGE et al., 2006). On the other hand, it also depends on genotyping for epidemiological investigation of the disease and identifying the source of infection.

Additional diagnostictests, confirmationofresults and reinvestigations are occasionally necessary, requiring the maintenance of mycobacterial isolates without any changes (GROVER et al., 1967; KIM; KUBICA, 1972; SMITH; RYAN, 2012). Longterm, well-preserved living organisms are equally required for research and development of new biotechnological techniques (SHU et al., 2012; SMITH; RYAN, 2012).
Maintenance through subculture often causes changes in the biochemical properties and the virulence of microorganisms, in addition to the occurrence of contamination (GRUFT et al., 1968). Lyophilization can preserve mycobacteria for years, but the process may result in an initial kill of $40 \%$ (UNGAR, 1949). This method exhibits low survival rate mainly for $M$. tuberculosis and $M$. bovis (SLOSAREK et al., 1976), and has been considered as ineffective for storing mycobacteria (GRUFT et al., 1968).

Cryopreservation is a simpler and more reliable method that allows long-term and stable storage of microorganisms (TARSHIS, 1961; GRUFT et al., 1968; SMITH; RYAN, 2012). The storage temperature and the composition of the suspending vehicle are among the factors that affect the viability of $M$. tuberculosis complex (MTC) strains (HUBÁLEK, 2003; HUANG et al., 2005; SHU et al., 2012).

Studies concerning both factors have been performed with several mycobacterial species (TARSHIS, 1961; KIM; KUBICA, 1973; KUBICA et al., 1977), including MTC organisms (GROVER et al., 1967; KIM; KUBICA, 1972; HUANG et al., 2005; SHU et al., 2012). Broth media, like Dubos Tween-albumin broth and Middlebrook 7H9 liquid medium supplemented with OADC enrichment, have been indicated as freezing suspensions for 
storage at $-70^{\circ} \mathrm{C}$ (GROVER et al., 1967; KIM; KUBICA, 1972; KIM; KUBICA, 1973; HUANG et al., 2005; SHU et al., 2012).

Despite these studies, none has focused on $M$. bovis field strains and their pyruvate requirement feature. In order to define a suitable cryoprotective medium for preserving $M$. bovis strains at sub-zero temperatures, the present study was designed to verify their viability on Stonebrink medium after freezing and thawing procedures.

\section{Material and Methods}

Sixteen $M$. bovis isolates, previously cultured and identified by spoligotyping (ROSALES RODRIGUEZ, 2005), were selected. Colonies of each sample were harvested from Stonebrink medium using disposable bacteriological loops humidified with Tween 80 , and transferred to tubes containing $5 \mathrm{~mL}$ sterile $0.85 \%$ saline solution.

The suspensions were adjusted to match the 0.5 McFarland turbidity standard. One milliliter of all suspensions was added to $9 \mathrm{~mL}$ of each vehicle: sterile $0.85 \%$ saline solution (SS), Middlebrook 7H9 broth (7H9) (according to the manufacturer's instructions; Becton, Dickinson and Company, Sparks, MD, USA), and Middlebrook 7H9 broth with $0.4 \%$ sodium pyruvate instead of glycerol (7H9p). Both $7 \mathrm{H} 9$ and $7 \mathrm{H} 9 \mathrm{p}$ were supplemented with $10 \%$ OADC enrichment (BD Diagnostics, Sparks, MD, USA). Aliquots of these suspensions were frozen by three different methods, directly in the $-20^{\circ} \mathrm{C}$ freezer, directly in the $-80^{\circ} \mathrm{C}$ freezer, and at $-196^{\circ} \mathrm{C}$ through direct immersion in liquid nitrogen (LN), and were thawed at room temperature after 45, 90 and 120 days.

In order to compare the survival rate, the suspensions in SS, 7H9 and 7H9p were diluted in sterile $0.85 \%$ saline solution before and after each freezing procedure. Three 10-fold dilutions, $10^{-1}, 10^{-2}$ and $10^{-3}$, were made before freezing, and four dilutions, $10^{-1}, 10^{-2}, 10^{-3}$ and $10^{-4}$, were made after freezing. From all the diluted suspensions, $0.1 \mathrm{~mL}$ was inoculated into duplicate petri dishes of Stonebrink medium followed by incubation at $37^{\circ} \mathrm{C}$. The cultures were observed after 30 days of incubation. The number of colonies was scored on the highest dilution cultured and was weighted to obtain the number of colony forming units (CFU) per $0.1 \mathrm{~mL}$ suspension.

For analysis, the loss proportion was calculated according to the following formula:

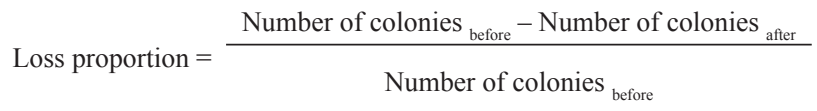

The Friedman's test followed by the Dunn's test of multiple comparisons was applied on the loss proportion data of cryopreservation media, the freezing procedures, and the thawing time. All tests were performed using the GraphPad InStat program with $\mathrm{p}<0.05$ considered as statistically significant.

\section{Results}

The cryopreservation media and freezing procedures were analyzed only at 45 days of thawing (Table 1). Due to the high percentage of contaminated culture plates at 90 and 120 days of thawing, it was not possible to assess the data of these thawing times.

A statistically significant difference was observed among freezing procedures (Friedman's test, $\mathrm{p}=0.0006$ ). Storage at $-20^{\circ} \mathrm{C}$ exhibited a higher loss proportion compared to $-80^{\circ} \mathrm{C}$ (Dunn's test, $\mathrm{p}=0.0018$ ) and LN (Dunn's test, $\mathrm{p}=0.0352$ ), while there was no difference between the latter two conditions (Dunn's test, $\mathrm{p}=0.1403$ ).

Regarding the cryopreservation media, no statistically significant difference was detected (Friedman's test, $\mathrm{p}=0.7765$ ). 
Table 1. Median of loss proportion on 45 days of thawing according to storage temperature and suspending vehicle.

\begin{tabular}{ccccc}
\hline \multirow{2}{*}{ Suspending vehicle } & \multicolumn{4}{c}{ Storage temperature } \\
\cline { 2 - 5 } & $-20^{\circ} \mathrm{C}$ & $-80^{\circ} \mathrm{C}$ & $-196^{\circ} \mathrm{C}$ & Total \\
\hline SS & $5,8 \%^{\mathrm{a}}$ & $0,3 \%^{\mathrm{b}}$ & $0,6 \%^{\mathrm{b}}$ & $2,5 \%$ \\
$7 \mathrm{H} 9$ & $5,3 \%^{\mathrm{a}}$ & $1,8 \%^{\mathrm{b}}$ & $1,2 \%{ }^{\mathrm{b}}$ & $3,0 \%$ \\
$7 \mathrm{H} 9 \mathrm{p}$ & $1,3 \%^{\mathrm{a}}$ & $1,2 \%{ }^{\mathrm{b}}$ & $3,0 \%{ }^{\mathrm{b}}$ & $2,4 \%$ \\
Total & $5,0 \%$ & $0,8 \%$ & $2,4 \%$ & \\
\hline
\end{tabular}

a, ${ }^{a}$ different letters mean statistical difference.

\section{Discussion}

Well-preserved living organisms are basic elements for research and biotechnology (SMITH; RYAN, 2012), especially when their purpose is the prevention and treatment of diseases. The importance on this matter can be highlighted by the International Standard Criteria (KIM; KUBICA, 1972; SMITH; RYAN, 2012) of the World Federation for Culture Collection (http://www.wfcc.info/guidelines/).

Among several studies performed, comparison between storage at $-20^{\circ} \mathrm{C}$ and $-70^{\circ} \mathrm{C}$, which is very close to $-80^{\circ} \mathrm{C}$, showed results of mycobacterial viability favored by $-70^{\circ} \mathrm{C}$ (GROVER et al., 1967; KIM; KUBICA, 1972, 1973). Our findings presented a higher loss proportion of $M$. bovis organisms stored at $-20^{\circ} \mathrm{C}$ compared to the lower temperatures.

Moreover, prolonged storage at $-20^{\circ} \mathrm{C}$ induces more viability losses in $M$. bovis and M. tuberculosis (KIM; KUBICA, 1973), and occasionally less than $0.0002 \%$ of the starting suspension remains viable (KIM; KUBICA, 1972). Although most other species of mycobacteria are able to survive equally well when stored at $-20^{\circ} \mathrm{C}$ and $-70^{\circ} \mathrm{C}$, cultures at $-20^{\circ} \mathrm{C}$ consistently yield lower numbers of living cells than those stored at $-70^{\circ} \mathrm{C}$ (KIM; KUBICA, 1973). Storage at $-196^{\circ} \mathrm{C}$ has displayed no differences compared to at $-80^{\circ} \mathrm{C}$ in the present study, or at $-70^{\circ} \mathrm{C}$ as reported by Grover et al. (1967).

Besides storage temperature, the procedure used for freezing the organisms is another issue that must be considered in culture maintenance. The cooling rate exhibited a significant and consistent effect on BCG cells to survive freezing and thawing (SHU et al., 2012). Survival rates are higher when the cells are submitted to slow rather than rapid cooling (GROVER et al., 1967; SHU et al., 2012).

The suspensions placed directly into $-20^{\circ} \mathrm{C}$ and $-80^{\circ} \mathrm{C}$ freezers were allowed to slowly cool and freeze, as demonstrated in other studies (GROVER et al., 1967; KIM; KUBICA, 1973). In contrast, their counterparts stored at $-196^{\circ} \mathrm{C}$, froze rapidly due to direct immersion in LN. Storage at $-80^{\circ} \mathrm{C}$ presented better results than LN considering the loss proportion. Nevertheless, the cooling rate did not have a significantly difference on cell viability between $-80^{\circ} \mathrm{C}$ and $\mathrm{LN}$.

Cryopreservation medium is considered to have a great influence on cell recovery (HUANG et al., 2005; SHU et al., 2012). However, the present work found no difference among SS, 7H9 and 7H9p. Other studies have included several types of suspending vehicles (i.e., media, skimmed milk, solutions with salts or sugars) and showed no difference either (TARSHIS, 1961; KIM; KUBICA, 1972; HUANG et al., 2005; SHU et al., 2012).

Due to the harmful effect of sub-zero temperatures, cryoprotective agents are commonly recommended for better preservation of microorganisms (HUBÁLEK, 2003; SMITH; RYAN, 2012). One of the most known and applied agent used to reduce risks of cryoinjury is glycerol (GROVER et al., 1967; GIAMPAGLIA et al., 2009; SHU et al., 2012). The standard formulation of Middlebrook $7 \mathrm{H} 9$ broth contains glycerol at a very 
low concentration $(0.2 \%)$, yet this cryoprotective agent at $4-5 \%$ did not reveal any significant benefits (GROVER et al., 1967; SHU et al., 2012).

Cryopreservation leans on storage temperature and cooling rate for prolonged survival of mycobacteria (GROVER et al., 1967; KIM; KUBICA, 1972, 1973; HUANG et al., 2005; SHU et al., 2012). Despite of progressive decrease of viable cells occurs with increase in storage period (GROVER et al., 1967; HUANG et al., 2005; GIAMPAGLIA et al., 2009), this method is still considered the most reliable to ensure viability and infectivity (KIM; KUBICA, 1973; SMITH; RYAN, 2012)

\section{Conclusion}

The results of the present work confirm the great importance of storage temperature rather than suspending medium in cryopreservation. Although storage at $-20^{\circ} \mathrm{C}$ displayed statistically inferior results compared to $-80^{\circ} \mathrm{C}$ and $\mathrm{LN}$, the loss proportion of $5 \%$ is still very low. Moreover, storage at $-80^{\circ} \mathrm{C}$ and $\mathrm{LN}$ require high cost equipment, and the latter also requires high cost maintenance, which can be considered as unfavorable.

Preservation of $M$. bovis field strains aiming epidemiological investigations will supply further tools to the Brazilian Program of Control and Eradication of Animal Brucellosis and Tuberculosis. Therefore, we recommend storage of these strains at $-20^{\circ} \mathrm{C}$ or at $-80^{\circ} \mathrm{C}$, when the equipment is available.

\section{Acknowledgements}

The authors acknowledge the logistical and financial support from CAPES, CNPq and FAPESP.

\section{References}

BAHIENSE, L.; ÁVILA, L. N. de; BAVIA, M. E.; AMAKU, M.; DIAS, R. A.; GRISI-FILHO, J. H. H.; FERREIRA, F.; TELLES, E. O.; GONÇALVES, V. S. P.; HEINEMANN, M. B.; FERREIRA NETO, J. S. Prevalence and risk factors for bovine tuberculosis in the State of Bahia, Brazil. Semina: Ciências Agrárias, Londrina, v. 37, n. 5, p. 3549-3560, 2016. Suplemento 2.

BARBIERI, J. M.; OLIVEIRA, L. F.; DORNELES, E. M. S.; MOTA, A. L. A. A.; GONÇALVES, V. S. P.; MALUF, P. P.; FERREIRA NETO, J. S.; FERREIRA, F.; DIAS, R. A.; TELLES, E. O.; GRISI-FILHO, J. H. H.; HEINEMANN, M. B.; AMAKU, M.; LAGE, A. P. Epidemiological status of bovine tuberculosis in the state of Minas Gerais, Brazil, 2013. Semina: Ciências Agrárias, Londrina, v. 37, n. 5, p. 3531-3548, 2016. Suplemento 2.

DIAS, R. A.; STANOJLOVIC, F. M. U.; BELCHIOR, A. P. C.; FERREIRA, R. S.; GONÇALVES, R. C.; AGUIAR, R. S. C. B.; SOUSA, P. R.; SANTOS, A. M. A.; AMAKU, M.; FERREIRA, F.; TELLES, E. O.; GRISI-FILHO, J. H. H.; GONÇALVES, V. S. P.; HEINEMANN, M. B.; FERREIRA NETO, J. S. Prevalence and risk factors for bovine tuberculosis in the state of São Paulo, Brazil. Semina: Ciências Agrárias, Londrina, v. 37, n. 5, p. 3673-3684, 2016. Suplemento 2.

GALVIS, J. O. A.; GRISI-FILHO, J. H. H; COSTA, D.; SAID, A. L. P. R.; AMAKU, M.; DIAS, R. A.; FERREIRA, F.; GONÇALVES, V. S. P.; HEINEMANN, M. B.; TELLES, E. O.; FERREIRA NETO, J. S. Epidemiologic characterization of bovine tuberculosis in the state of Espírito Santo, Brazil. Semina: Ciências Agrárias, Londrina, v. 37, n. 5, p. 3567-3578, 2016. Suplemento 2.

GIAMPAGLIA, C. M.; BRITO, A. C. de; MARTINS, M. C.; UEKI, S. Y.; LATRILHA, F. O.; OLIVEIRA, R. S. de; YAMAUCHI, J. U.; SILVA TELLES, M. A. da. Maintenance of Mycobacterium tuberculosis on glass beads. Annals of Clinical and Laboratory Science, Philadelphia, v. 39, n. 1, p. 51-54, 2009.

GROVER, A. A.; KIM, H. K.; WIEGESHAUS, E. H.; SMITH, D. W. Host-parasite relationships in experimental airborne tuberculosis II. Reproducible infection by means of an inoculum preserved at $-70^{\circ} \mathrm{C}$. Journal of Bacteriology, Washington, v. 94, n. 4, p. 832$835,1967$. 
GRUFT, H.; CLARK, M. E.; OSTERHOUT, M. Preservation of mycobacterial cultures. Applied Microbiology, Washington, v. 16, n. 2, p. 355-357, 1968.

GUEDES, I. B.; BOTTENE, I. F. N.; MONTEIRO, L. A. R. C.; LEAL FILHO, J. M.; HEINEMANN, M. B.; AMAKU, M.; GRISI-FILHO, J. H. H.; DIAS, R. A.; FERREIRA, F.; TELLES, E. O.; GONÇALVES, V. S. P.; FERREIRA NETO, J. S. Prevalence and risk factors for bovine tuberculosis in the state of Mato Grosso do Sul, Brazil. Semina: Ciências Agrárias, Londrina, v. 37, n. 5, p. 3579-3588, 2016. Suplemento 2.

HUANG, T. S.; CHEN, Y. S.; LEE, S. S.; TU, H. Z.; LIU, Y. C. Preservation of clinical isolates of Mycobacterium tuberculosis complex directly from MGIT culture tubes. Annals of Clinical and Laboratory Science, Philadelphia, v. 35, n. 4, p. 455-458, 2005.

HUBÁLEK, Z. Protectants used in the cryopreservation of microorganisms. Cryobiology, Rockville, v. 46, n. 3, p. 205-229, 2003.

KIM, T. H.; KUBICA, G. P. Long-term preservation and storage of mycobacteria. Applied Microbiology, Washington, v. 24, n. 3, p. 311-317, 1972.

Preservation of mycobacteria: $100 \%$ viability of suspensions stored at $-70^{\circ} \mathrm{C}$. Applied Microbiology, Washington, v. 25, n. 6, p. 956-960, 1973.

KUBICA, G. P.; GONTIJO-FILHO, P. P.; KIM, T. Preservation of mycobacteria at $-70^{\circ} \mathrm{C}$ : persistence of key differential features. Journal of Clinical Microbiology, Washington, v. 6, n. 2, p. 149-153, 1977.

LAGE, A. P.; ROXO, E.; MÜlLER, E.; POESTER, F.; CAVAllÉRO, J. C. M.; FERREIRA NETO, J. S.; MOTA, P. M. P. C.; GONÇALVES, V. S. P. Programa nacional de controle e erradicação da brucelose e da tuberculose animal (PNCEBT). Brasília: Ministério da Agricultura, Pecuária e Abastecimento, 2006. 184 p. (Manual técnico).

LIMA, P. B.; NASCIMENTO, D. L.; ALMEIDA, E. C.; PONTUAL, K. A. Q.; AMAKU, M.; DIAS, R. A.; FERREIRA, F.; GONÇALVES, V. S. P.; TELLES, E. O.; GRISI-FILHO, J. H. H.; HEINEMANN, M. B.; SILVA, J. C. R.; FERREIRA NETO, J. S. Epidemiological situation of bovine tuberculosis in the state of Pernambuco, Brazil. Semina: Ciências Agrárias, Londrina, v. 37, n. 5, p. 3601-3610, 2016. Suplemento 2.

NÉSPOLI, J. M. B.; NEGREIROS, R. L.; AMAKU, M.; DIAS, R. A.; FERREIRA, F.; TELLES, E. O.; HEINEMANN, M. B.; GRISI-FILHO, J. H. H.; GONÇALVES, V. S. P.; FERREIRA NETO, J. S. Epidemiological situation of bovine tuberculosis in the state of Mato Grosso, Brazil. Semina: Ciências Agrárias, Londrina, v. 37, n. 5, p. 3589-3600, 2016. Suplemento 2.

QUEIROZ, M. R.; GROFF, A. C. M.; SILVA, N. S.; GRISI-FILHO, J. H. H.; AMAKU, M.; DIAS, R. A.; TELLES, E. O.; HEINEMANN, M. B.; FERREIRA NETO, J. S.; GONÇALVES, V. S. P. FERREIRA, F. Epidemiological status of bovine tuberculosis in the state of Rio Grande do Sul, Brazil. Semina: Ciências Agrárias, Londrina, v. 37, n. 5, p. 3647-3658, 2016. Suplemento 2.

RIBEIRO, L. A.; GONÇALVES, V. S. P.; FRANCISCO, P. F. C.; MOTA, A. L. A. A.; NASCIMENTO, G. T.; LICURGO, J. B.; FERREIRA, F.; GRISI-FILHO, J. H. H.; FERREIRA NETO, J. S.; AMAKU, M.; DIAS, R. A.; TELLES, E. O.; HEINEMANN, M. B.; BORGES, J. R. J. Epidemiological status of bovine tuberculosis in the Federal District of Brazil. Semina: Ciências Agrárias, Londrina, v. 37, n. 5, p. 3561-3566, 2016. Suplemento 2.

ROCHA, W. V.; JAYME, V. S.; MOTA, A. L. A. A.; BRITO, W. M. E. D; PIRES, G. R. C; GRISI-FILHO, J. H. H; DIAS, R. A.; AMAKU, M.; TELLES, E. O.; HEINEMANN, M. B.; FERREIRA, F.; FERREIRA NETO, J. S.; GONÇALVES, V. S. P. Prevalence and herd-level risk factors of bovine tuberculosis in the State of Goiás, Brazil. Semina: Ciências Agrárias, Londrina, v. 37, n. 5, p. 3625-3628, 2016. Suplemento 2.

ROSALES RODRIGUEZ, C. A. Sistema de detecção de focos de tuberculose bovina no Estado de São Paulo utilizando métodos moleculares e epidemiológicos. 2005. Tese (Doutorado em Medicina Veterinária) - Faculdade de Medicina Veterinária e Zootecnia, Universidade de São Paulo, São Paulo.

SHU, Z.; WEIGEL, K. M.; SOELBERG, S. D.; LAKEY, A.; CANGElOSI, G. A.; LEE, K. H.; CHUNG, J. H.; GAO, D. Cryopreservation of Mycobacterium tuberculosis complex cells. Journal of Clinical Microbiology, Washington, v. 50, n. 11, p. 3575-3580, 2012.

SILVA, M. C. P.; GONÇALVES, V. S. P.; MOTA, A. L. A. A.; KOLODA, M.; FERREIRA NETO, J. S.; GRISIFILHO, J. H. H; DIAS, R. A.; AMAKU, M.; TELLES, E. O.; FERREIRA, F.; HEINEMANN, M. B.; ALFIERI, A. A.; MULLER, E. E. Prevalence and herd-level risk factors for bovine tuberculosis in the state of Paraná, Brazil. Semina: Ciências Agrárias, Londrina, v. 37, n. 5, p. 3611-3624, 2016. Suplemento 2.

SLOSAREK, M.; SOUREK, J.; MIKOVÁ, Z. Results of long-term preservation of mycobacteria by means of freeze-drying. Cryobiology, Rockville, v. 13, n. 2, p. 218224, 1976. 
SMITH, D.; RYAN, M. Implementing best practices and validation of cryopreservation techniques for microorganisms. The Scientific World Journal, Boynton Beach, v. 2012, ID 805659, p. 1-9, 2012.

TARSHIS, M. S. The preservation of mycobacteria by freezing in various diluents. The American Review of Respiratory Disease, Baltimore, v. 83, n. 5, p. 762-766, 1961.

UNGAR, J. Viability of freeze-dried BCG cultures. Tubercle, Edinburgh, v. 30, n. 1, p. 2-4, 1949.

VELOSO, F. P.; BAUMGARTEN, K. D.; MOTA, A. L. A. A.; FERREIRA, F.; FERREIRA NETO, J. S.;
GRISI-FILHO, J. H. H.; DIAS, R. A.; AMAKU, M.; TELLES, E. O.; HEINEMANN, M. B.; GONÇALVES, V. S. P. Prevalence and herd-level risk factors of bovine tuberculosis in the State of Santa Catarina, Brazil. Semina: Ciências Agrárias, Londrina, v. 37, n. 5, p. 36593672, 2016. Suplemento 2.

VENDRAME, F. B.; AMAKU, M.; FERREIRA, F.; TELLES, E. O.; GRISI-FILHO, J. H. H.; GONÇALVES, V. S. P.; HEINEMANN, M. B.; FERREIRA NETO, J. S.; DIAS, R. A. Epidemiologic characterization of bovine tuberculosis in the State of Rondônia, Brazil. Semina: Ciências Agrárias, Londrina, v. 37, n. 5, p. 3639-3646, 2016. Suplemento 2. 
